\title{
Influence of technological parameters on the degree of enzymatic hydrolysis of high-protein products
}

\author{
Lesia Avdieiea, Eduard Zhukotskyi, Hanna Dekusha
}

\author{
Institute of engineering thermophysics of National Academy of Sciences of \\ Ukraine, Kyiv, Ukraine
}

Keywords:

Protein

Hydrolysis

Proteases

Amino acids

\section{Article history:}

Received 21.10.2018

Received in revised

form 12.09.2019

Accepted 28.11.2019

\section{Corresponding}

author:

Lesia Avdieiea

E-mail:

tbds_ittf@ukr.net

DOI: $10.24263 / 2304-$

974X-2019-8-4-13

\section{Abstract}

Introduction. Research have been conducted to determine the influence of technological parameters on the degree of hydrolysis of soy and whey proteins, as well as their mixtures to obtain balanced protein compositions with a high degree of hydrolysis.

Materials and methods. Researched here are isolated soy protein, whey protein concentrate and mixtures at different ratio thereof that were hydrolyzed by proteases «Protamex», «Bioprotease N100L» and «Profix 6500». A degree of protein hydrolysis was evaluated by spectrophotometric method, the amino acid composition of hydrolysates was determined using ion exchange chromatography.

Results and discussion. To obtain a highly hydrolyzed isolated soy protein rational modes of its proteolysis were determined, namely: mass concentration of protein in an aqueous solution $-9 \%$, mass concentration of protease $-5 \%$, $\mathrm{pH}$ 6.5-7.0, hydrolysis temperature $55-60{ }^{\circ} \mathrm{C}$ and duration of the process $-60 \mathrm{~min}$. Under these conditions, the degree of hydrolysis of isolated soy protein is $80-82 \%$ obtained with «Protamex», 50-51\% - with «Bioprotease N100L» and 30$33 \%$ - with «Profix 6500».

Hydrolytic effect of the above mentioned proteases on the degree of hydrolysis of whey protein concentrate under the same conditions is slightly less and amounts to $45-46 \%$ for «Protamex», 30-33\% for «Bioprotease N100L» and 19-20\% for «Profix 6500» which can be explained by the smaller specificity of this substrate to the enzymes.

To achieve a balanced composition of essential amino acids relative to human milk, it is rational to combine a whey protein concentrate and isolated soy protein in a mass ratio of 1:1 respectively. In doing so, the degree of hydrolysis of this mixture is high and amounts to more than $80 \%$ under the action of «Protamex» at a concentration of $5 \%$ by weight of protein, a temperature of $55-60{ }^{\circ} \mathrm{C}$ and a duration of 60 minutes.

Conclusions. For the first time the rational technological parameters for the proteolysis of isolated soy protein, whey protein concentrate and their mixtures were determined to obtain a high degree of hydrolysis. 


\section{Introduction}

A process of enzymatic protein hydrolysis is an interesting scientific and practical problem. It is of relevance because it allows to solve the problems of enrichment of food products with valuable biologically active components. The hydrolysis application increases the nutritional and biological value of proteins, improves their absorption and changes their functional properties as well $[1,2]$.

Furthermore, proteolysis is an effective way to reduce the antigenic properties of food proteins. Depending on the type of protease and the conditions of the process, peptides with different molecular weights and free amino acids are formed. Such properties make them possible to introduce to the composition of dietary products, medical $[3,4]$, sports nutrition $[5,6]$ as well as in the production of hypoallergenic formulae for enteral and baby nutrition $[7,8]$.

Due to the complexity and multifactor nature of the process and taking into account the high social need for products with hydrolyzed protein, the determination of rational conditions for the process of proteolysis remains relevant.

To obtain hydrolysates, various raw materials of animal (dairy, meat, fish) and vegetable (soy, lentils, beans, chickpeas) origin with a high protein content are used. Thus, the protein component of modern hypoallergenic formulae for infants is represented by extensively or partially hydrolysated milk proteins [9], such as whey, casein proteins or mixtures thereof [10]. Although whey proteins have a balanced composition of essential amino acids [11], $\beta$-lactoglobulin, which accounts for $58 \%$ of whey proteins (12\% of total protein), has the highest allergenic potential $[12,13]$. To reduce its antigenic properties, milk raw materials can traditionally be heat-treated $\left(145^{\circ} \mathrm{C}\right.$ during 2 to $3 \mathrm{~s}$ [14]), however, the thermal denaturation can lead to both destruction and exposure of hidden areas of antigenic determinants and also to the aggregation of protein molecules $[15,16]$.

Researchers offer different solutions to the problem of reducing antigenicity due to hydrolysis of proteins under different conditions by enzymes of animal (trypsin, pepsin), microbial (obrained from Bacillus licheniformis (commercially known as Alcalase), Aspergillus oryzae (Flavourzyme), Bacillus amyloliquefaciens (Neutrase) and etc.) and plant origin (bromelain, papain, physyn) or their complexes (Protamex).

Among the advantages of whey protein proteolysis are the high nutritional and biological value of the obtained hydrolysates $[11,17,18]$, their increased digestibility and solubility even with a small degree of hydrolysis (5-20\%) [19] as well as antioxidant activity [20]. It should be noted that different authors received slightly different data depending on the method for determiming and used equipment.

The main problem of protein hydrolysates is, as known, their bitter taste [21-23] due to what is believed to be the formation of peptides with hydrophobic amino acids [24]. They are trying to reduce it applying additional ultrafiltration [25, 26], cleavage with exo- and endopeptidases [27, 28] or adding taste-masking components [29].

Among other disadvantages, a significant duration of the process and the high cost of enzyme preparations, especially of animal origin, for example, trypsin should be taken into consideration [1].

Based on the results of modeling of the hydrolysis process with the Peptide Cutter program it was determined that from the point of view of residual antigenicity, the hydrolysis of whey proteins with Protamex, Alcalase and thermolysin is optimal [30, 31].

It is possible to achieve different degree of hydrolysis of whey proteins by changing the technological conditions and using different proteases. For instance, the degree of hydrolysis of whey proteins after proteolysis with trypsin, rennin, papain and pepsin within 4 hours 
reached $61.4,84.2,95$ and $100 \%$ respectively. Subsequent ultrafiltration of peptides further reduces antigenicity [25] but as a result there is an imbalance in the amino acid composition of milk proteins. While the hydrolysis of $\alpha$-lactalbumin with trypsin its complete degradation in 15-120 minutes is noted. A complete cleavage of $\beta$-lactoglobulin requires an increase in the process duration up to 450-1200 $\mathrm{min}$ and depends on the type of combination of conditions mentioned above [32].

In addition to milk proteins, soy proteins are often used to obtain therapeutic mixtures with hydrolysates. They are characterized by a high molecular weight (up to $380 \mathrm{kDa}$ [14]) which can also result in their antigenicity. Enzymatic hydrolysis of soy proteins improves its functional properties, such as emulsifying ability, solubility and formation of biologically active peptides [1]. Soy protein hydrolysates [14, 33, 34] have the same features as milk protein hydrolysates.

The degree of hydrolysis of soy proteins is low in most cases and only combined action of several proteases makes it possible to achieve the value up to $40 \%$. An increase in the degree of hydrolysis is also possible due to physical destruction of the protein structure applying high pressure, soft treatment with acids, ultrasound or extrusion [1].

At the same time, the fraction of soy peptides with a molecular weight $<10 \mathrm{kDa}$ is characterized by the highest antioxidant activity, namely, the ability to act as a metal-ion chelator, cleanse from free radicals, prevent lipid oxidation and so on[1].

An analysis of the literature research results suggests that the existing technological parameters of enzymatic hydrolysis in most cases are characterized by a significant process duration and low degree of protein hydrolysis. To increase the efficiency of the process additional research is needed.

The purpose of research is to determine the effect of technological parameters on the degree of hydrolysis of isolated soy protein and whey protein concentrate and their mixtures for obtaining balanced protein compositions of high degree of hydrolysis.

\section{Materials and methods}

Object of research: process ofenzymatic hydrolysis of isolated soy protein, whey protein concentrates and their mixtures.

\section{Research subjects:}

- Isolated soy protein Supro 1751 (further ISP) (protein content - 90\%, fat - 0,5\%, ash $-5,5 \%$, «Solae Europe, S.A.», USA);

- Whey protein concentrate WPC 80 (further WPC) (protein content - up to $82.5 \%$, fat $-5,2 \%$, ash $-2,3 \%$, «Agri-MarkInc.», USA);

- $\quad$ Mixture of isolated soy protein Supro 1751 and whey protein concentrate WPC 80 at ratio $1: 1$ and $1: 2$ respectively.

\section{Materials}

Neutral protease from Bacillus amyloliquefaciens [35]and Bacillus licheniformis [3638, 39] («Protamex», activity 1,5 AU/g, optimum pH 5,5-7,5, optimum temperature 35-60 ${ }^{\circ} \mathrm{C}$, "Novozymes", Denmark), neutral protease from Bacillus subtilis [40] («Bioprotease N100L», activity minimum 100,000 c.u. NPU/ml, optimum temperature $55-60^{\circ} \mathrm{C}$, optimum pH 7,0-8,0, Kerry Food Ingredients (Cork) Ltd, Ireland), neutral protease from papaya tree fruits («Profix 6500», activity 6500 units/mg, optimum $\mathrm{pH}$ 7.0-8.0, optimum temperature 
65-70 ${ }^{\circ} \mathrm{C}$, Kerry Food Ingredients (Cork) Ltd, Ireland) were used for hydrolys. All enzyme preparations are permitted for use in food industry [41].

\section{Preparation of hydrolyzed proteins}

Weighted protein samples were hydrated in distilled water at the temperature of $20^{\circ} \mathrm{C}$ $\left(\omega_{\text {protein }}=2,2-12,5 \%\right)$, thoroughly mixed, heated to the optimum temperature and proteases were added ( $\omega_{\text {protease }}=0,3-10 \%$ of protein mass). Protein hydrolysis was carried out at the optimum temperature of maximum enzyme activity for a certain time ( $\tau=20-90 \mathrm{~min})$. To stop the hydrolysis, the samples were heated to $85-90{ }^{\circ} \mathrm{C}$ and kept for 5-7 min at this temperature [42].

3-chloro-acetic acid (5\% in final mass concentration) was added to the samples to separate obtained hydrolysates from protein, and then they were centrifuged at Low speed centrifuge 310 (Poland) for $\tau=15 \mathrm{~min}$ at $15000 \mathrm{rpm}$ [43].

\section{Determination of degree of protein hydrolysis (HD)}

HD was determined by spectrophotometric technique on spectrophotometer CF-26 by changing light absorption of supernatant at a wavelength of $280 \mathrm{~nm}$. Calibration graph is based on bovine serum albumin $[44,45]$. HD was calculated by spectrophotometric method according to the ability of aromatic amino acids (tryptophan, tyrosine, phenylalanine) to absorb ultraviolet light with a maximum absorption at $280 \mathrm{~nm}$ [46].

\section{Determination of amino acid composition in samples}

Amino acid analysis was carried out by ion-exchange chromatography technique using an Amino Acid Analyzer T-339 (“Mikrotechna”, Czech Republic) [47].

\section{Results and discussion}

\section{Dependence of hydrolysis degree of ISP and WPC from protein concentration in water}

One of the main process parameters that affects $\mathrm{HD}$ is mass concentration ofproteinin water $\left(\omega_{\text {protein }}\right)$. Determining a rational amount of protein will provide necessary HD with minimum possible amount of water and reduction of energy consumption for moisture removal when the product is being concentrated and dried.

The determination of HD of ISP and WPC depending on mass concentration of protein in water was carried out at $\omega_{\text {protein }}=2,2 ; 3,2 ; 6,3 ; 9,0$ and $12,5 \%$. The mass concentration of the protease $\left(\omega_{\text {protease }}\right)$ for all samples remained unchanged ( $\omega_{\text {protease }}=5 \%$ by weight of protein $)$, the duration of hydrolysis was $\tau=60 \mathrm{~min}$ at the temperature $\mathrm{t}=55-60{ }^{\circ} \mathrm{C}$. The results of change in HD of ISP and WPC depending on $\omega_{\text {protein }}$ by different proteases are shown in Figure 1. 


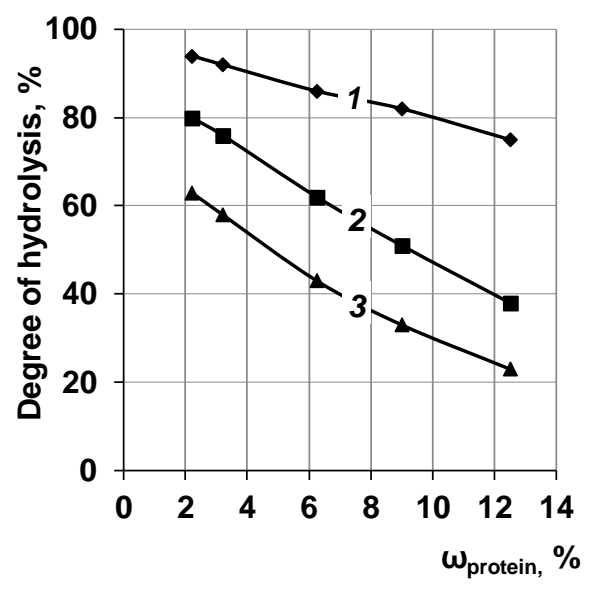

a

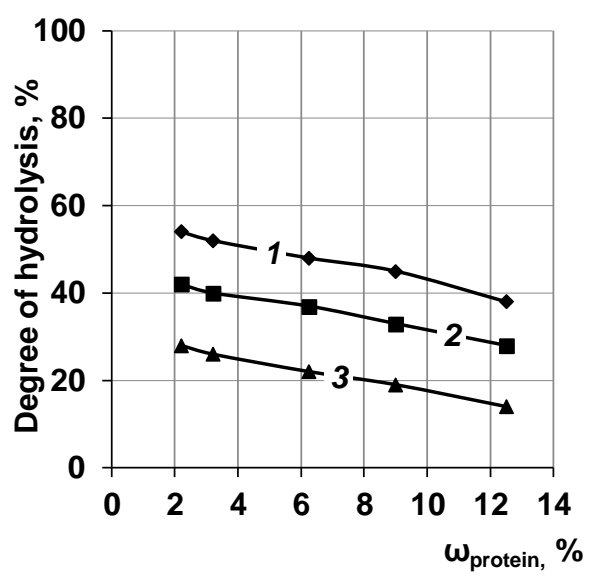

b

Figure 1. Dependence of hydrolysis degree of ISP (a) and WPC (b) samples from protein concentration in water $\left(\omega_{\text {protein }}\right)$ hydrolyzed by: 1 - «Protamex», 2 - «Bioprotease N100L», 3 - «Profix 6500».

As seen in Figure 1, HD of all high-protein products was inversely proportional to the protein mass concentration $\left(\omega_{\text {protein }}\right)$. Maximum HD of ISP was achieved at $\omega_{\text {protein }}=2,2 \%$ under action of «Protamex» and amounts 90\%. For data [35] Bacillus amyloliquefaciens, which is a part of «Protamex», showed significant improvement in nutritional quality and bioactivity by removing anti-nutritional factors as well as allergens. An aminopeptidase from Bacillus licheniformis, which is also is a part of «Protamex» showed high specificity for dipeptides with Leu, Val, Ala, Gly, and Phe at the N-terminus» as noticed in research [39]. In the hydrolysis of soy protein isolate Bacillus amyloliquefaciens preferred peptides with Leu, Glu, Gly, and Ala at the N-terminus by free amino acid analysis and preferred peptides with Leu, Ala, Ser, Trp and Tyr at the N-terminus by ultra performance liquid chromatograpy-MS/MS [39].

When using the «Bioprotease N100L» or «Profix 6500» the maximum HD of ISP was achieved at the same protein mass concentration and is about $80 \%$ and $63 \%$ respectively (Fig. 1a). But further reduction of $\omega_{\text {protein }}<2,2 \%$ in water is impractical due to the fact that a large amount of water demands extra energy on moisture evaporation. And an increase in the mass concentration of ISP in an aqueous solution, for example, from $\omega_{\text {protein }}=9 \%$ to $\omega_{\text {protein }}=$ $12,5 \%$, leads to a decrease in its HD by $10-25 \%$, depending on the type of protease.

Proteolysis of WPC by selected proteases at the same temperature-time parameters provided a significantly lower HD as compared with ISP (Figure 1b). It is hypothesized that B. licheniformis protease breaks down hydrophilic segments in the substrate and, therefore, preserves hydrophobic segments that aggregate once exposed to the solvent [37]. Thus, the highest degree of hydrolysis of WPC, obtained with $\omega_{\text {protein }}=2,2 \%$ and using «Protamex», was $55-58 \%$ that also in some way confirmed in [38]. When «Bioprotease N100L» and «Profix 6500» were used HD of WPC was 2-2,5 times lower as comrared with ISP. Subsequent investigations were carried out at a mass concentration of all proteins of $\omega_{\text {protein }}$ $=9 \%$. 


\section{Dependence of hydrolysis degree of ISP and WPC from protease concentration}

Results of research of HD depending on mass concentration of selected proteases $\left(\omega_{\text {protease }}\right)$ are shown in Fifure 2 . Experimental research were carried out at $\omega_{\text {protease }}=0,3 ; 0,5$; $1 ; 2,5 ; 5$ and $10 \%$ of mass of protein, $\omega_{\text {protein }}=9 \%$, hydrolysis time period is $\tau=60 \mathrm{~min}$, temperature $\mathrm{t}=55-60{ }^{\circ} \mathrm{C}$.

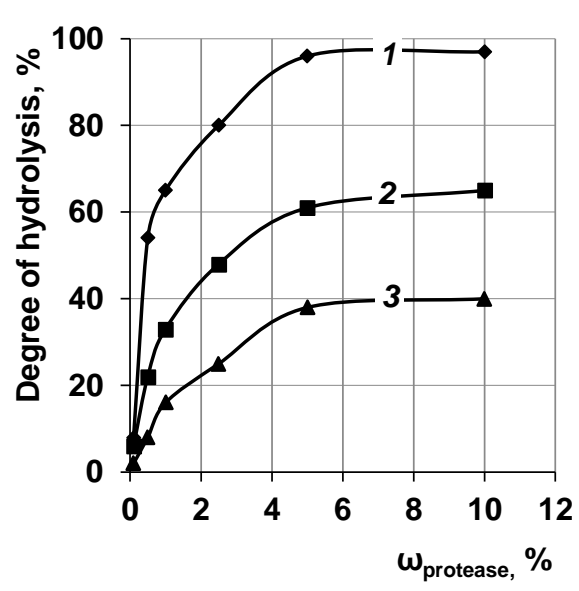

a

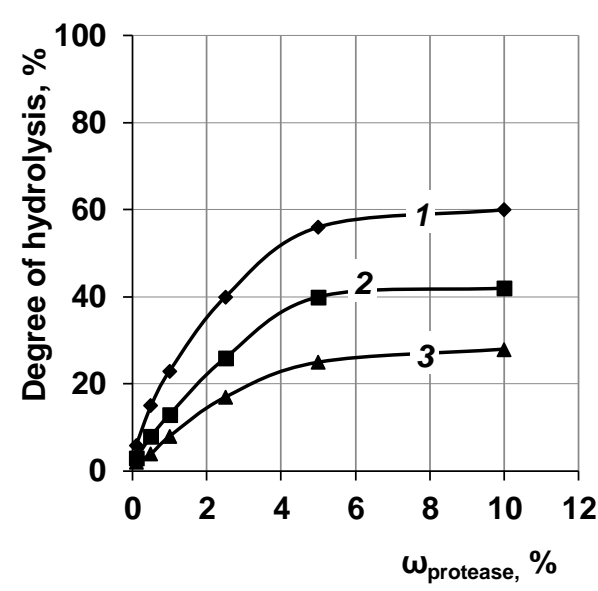

$\mathbf{b}$

Figure 2. Dependence of hydrolysis degree of ISP (a) and WPC (b) from protease concentration $\omega_{\text {protease: }} 1$ - «Protamex», 2 - «Bioprotease N100L», 3 - «Profix 6500».

Given in Figure 2 curves demonstrate a growth of HD of proteins when increase in $\omega_{\text {protease }}$ in all hydrolyzated samples. The highest growth rate of HD was observed at $\omega_{\text {protease }}=$ $0,3-5,0 \%$, further increase in $\omega_{\text {protease }}>6 \%$ have not provided significant change in HD. The highest HD by selected proteases was observed for ISP. Thus, proteolysis of ISP by «Protamex» allowed to obtain maximum HD (up to $90 \%$ ) at $\omega_{\text {protease }}=5 \%$ (Figure $2 \mathrm{a}$ ). «Bioprotease N100L» and «Profix 6500» cleavage ISP less than 60 and 40\% respectively. The intensity of hydrolysis of WPC was significantly lower as compared to ISP when determined after $60 \mathrm{~min}$ (fig. 2b). Maximum values of HD were achieved when «Protamex», «Bioprotease N100L» and «Profix 6500» were used at $\omega_{\text {protease }}=6-10 \%$ and accounted for 60,40 and $25 \%$ respectively.

\section{Dependence of hydrolysis degree of ISP and WPC from time}

Another necessary parameter that influences on protein hydrolysis and describes process dynamic is aperiod of time. HD of proteins was determined every 20 min during 90 min. Curves of proteolysis of ISP and WPC obtained when $\omega_{\text {protein }}=9 \%, \omega_{\text {protease }}=5 \%$ of mass of protein, temperature $\mathrm{t}=55-60^{\circ} \mathrm{C}$ are shown in Figure 3 . 


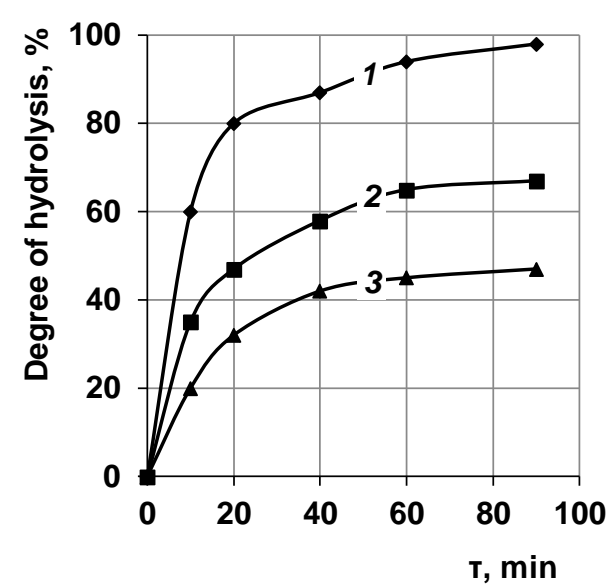

a

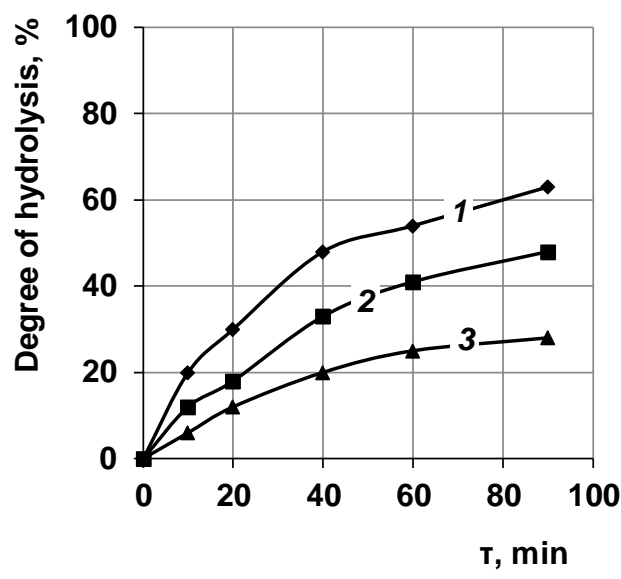

b

Figure 3. Dependence of HD of ISP (a) and WPC (b) from time: 1 - «Protamex», 2 - «Bioprotease N100L», 3 - «Profix 6500».

The highest process speedtook place during the first hourfor all samples. After that speed was slowed down and further hydrolysis gave only a slight increase in peptides (Figure 3 ). Reduction of the enzymatic reaction rate over timeis due to accumulation of reaction products and decrease in degree of saturation of the enzymes by substrate and partial inactivation of enzymes at given temperature and $\mathrm{pH}$. Thus, the most considerable change in HD was observed in ISP samples and it significantly depended on type of protease: when using «Protamex» HD was 82\%, «Bioprotease N100L»-48\% and «Profix 6500»-35\% after first $20 \mathrm{~min}$. After $20 \mathrm{~min}$ the intensity of the hydrolysis process decreases and over the next 40 min the degree of hydrolysis of ISP and WPC grew by only 10-30\%. Proteolysis of WPC was proceeding more slowly and in $60 \mathrm{~min}$ HD did not exceed 50-55\% under effect of «Protamex», 40-45\% - «Bioprotease N100L» and 25-27\% - «Profix 6500».

Summarized results of studies of HD of high-protein products by chosen proteases at $\omega_{\text {protein }}=9 \%$ and $\omega_{\text {protease }}=5 \%$ in 60 minare given in Table 1 .

HD of ISP and WPC obtained by different proteases

Table 1

\begin{tabular}{|l|c|c|c|}
\hline \multirow{2}{*}{ Protein product } & \multicolumn{3}{|c|}{ HD,\% } \\
\cline { 2 - 4 } & «Protamex» & «Bioprotease N100L» & «Profix 6500» \\
\hline ISP & $90-95$ & $60-65$ & $40-45$ \\
\hline WPC & $50-55$ & $43-45$ & $20-23$ \\
\hline
\end{tabular}

Analysing results given in Table 1 it may be concluded that the highest HD of the highprotein products was achieved under activity of «Protamex», lower HD was observed when «Bioprotease N100L» was used and the lowest HD was noted for «Profix 6500». The rationale of using «Protamex» in the preparation of hydrolysates from whey proteins with a high degree of hydrolysis is confirmed by the results of [RU 2012158005, Method of 
producing whey protein hydrolysate with high degree of hydrolysis and low residual antigenicity] and from SPI is shown in [RU 2299568C2 Method for the production of processed cheese, 48]. The effectiveness of the strain of Bacillus subtilis ("Bioprotease N100L") on the depth of hydrolysis of WPC was confirmed in studies $[49,50]$.

\section{Composition of essential amino acids of WPC, ISP and their mixtures}

Amino acid composition of ISP and WPC were balanced relatively to breast milk. The use of WPC adapts protein component of baby formulas to infant's organism needs, increase amount of tryptophan and cysteine and ensure high level of digestion.The use of ISP also improvesthe amino acid composition bringing it closer to breast milk, increases biological value and digestion of product, reduces osmolarity and therefore a strain on infant's kidneys.The presence of hydrolyzed soy proteins in infant formulas (for example, «Gerber Good Start Soy Stage», Nestle) have been demonstrated in other studies [33, 51].

Thereby, choice an appropriate ratio of WPC and ISP would bring closer essential amino acid composition to breast milk and baby's organism needs in optimal ratio, provide high level of amino acid assimilation and ensure physiological value of theend product.

Figure 4 demonstrates the composition of essential amino acids of ISP, WPC and their mixtures at different mass ratios as compared to breast milk.

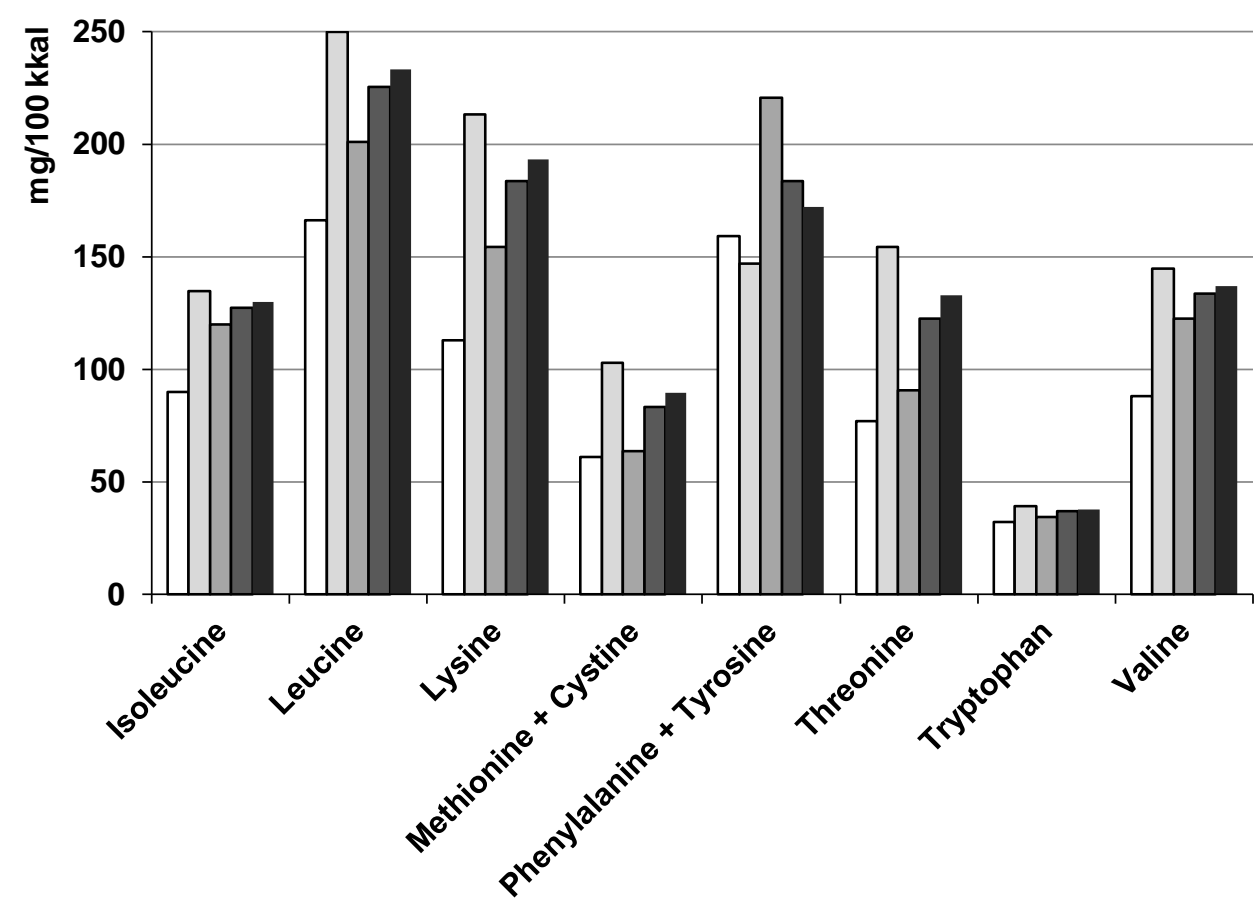

abreast milk $\quad$ 口WPC $\quad$ 口ISP $\quad$ 口WPC:ISP=1:1 $\quad$-WPC:ISP=2:1

Figure 4. The composition of essential amino acids of WPC, ISP and their mixtures at mass ratio 1:1 and 2:1 respectively as compared to breast milk. 
WPC and ISP at mass ratio of 1:1 and 2:1 respectively have a highly balanced formula of essential amino acids to breast milk. Content of essential is leucine, tryptophan, valine, phenylalanine, tyrosine and especially lysine and threonine are close to their content in breast milk.

Shown in Figure 5 is dependence of HD of WPC and ISP mixtures from mass concentration of «Protamex» with ratio of 1:1 and 2:1 respectively at the temperature $t=55$ $60{ }^{\circ} \mathrm{C}$ in $60 \mathrm{~min}$.

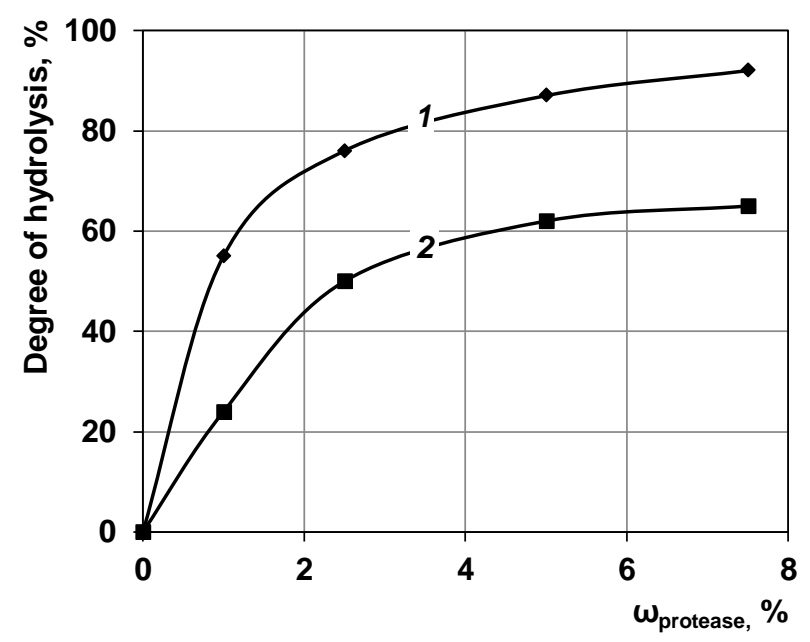

Figure 5. Dependence of HD of WPC and ISP mixtures from mass concentration of «Protamex» with mass ratio: $1-1: 1,2-2: 1$

The results (Figure 5) indicated high efficiency of «Protamex» application for proteolysis of WPC and ISP mixture with both ratios. The highest intensity of HD growth was observed in samples that contained $\omega_{\text {protease }}=2,5 \%$. Further increase in mass concentration of «Protamex» didn't provide a significant increase in HD. Maximum HD was observed in sample containing mixture of ISP and WPC with mass ratio of 1:1, respectively, when $\omega_{\text {protease }}=7,5 \%$, although a high value of $\mathrm{HD}$ was already achieved at $\omega_{\text {protease }}=5 \%$ and was $70-75 \%$.

Thus, conducted studies allowed to characterize proteolysis of dry high-protein products and their mixtures, obtain kinetic dependences depending on changing technological conditions and type of enzyme and choose rational technological parameters to achieve the goal.

\section{Conclusion}

Research of the influence of technological parameters on the degree of enzymatic hydrolysis of ISP and WPC by proteases «Protamex», «Bioprotease 100L» and «Profix 6500» were carried out.

Dependence of degree of enzymatic hydrolysis of ISP and WPCand their mixtures from mass concentration of proteins, proteases and incubation time are shown. Rational 
technological parameters for each of the high-protein products and their mixtures were chosen: the mass concentration of protein is $\omega_{\text {protein }}=9 \%$ under the action of «Protamex» $\left(\omega_{\text {protease }}=5 \%\right)$ for $60 \mathrm{~min}$. The degree of protein hydrolysis for these conditions of enzymatic hydrolysis for ISP is up to $90 \%$, for WPC is up to 55\%, for a mixture of ISP and WPC in a ratio of $1: 1$, respectively, is $85 \%$.

The rational ratio of ISP and WPC for maximum approximation to the composition of the essential amino acids of human milk is 1:1 respectively.

Obtained hydrolysates can be the basis of protein component in infant's hypoallergenic formulas.

\section{References}

1. Dong X. (2011), Enzymatic hydrolysis of soy proteins and the hydrolysates utilization, International Journal of Food Science and Technology, 12(46), pp. 2447-2459.

2. Wouters A., Rombouts I., Fierens E. et. al (2016), Relevance of the functional properties of enzymatic plant protein hydrolysates in food systems, Comprehensive Reviews in Food Science and Food Safety, 15, pp. 786-800.

3. Chalamaiah M., $\mathrm{Yu}$ W., Wu J. (2018), Immunomodulatory and anticancer protein hydrolysates (peptides) from food proteins: A review, Food chemistry, 245, pp. 205-222.

4. Zadak Z., Kent-Smith L. (2009), Basic in clinical nutrition: Commercially prepared formulas, e-SPEN, the European e-Journal of Clinical Nutrition and Metabolism, 4(5), pp. 212-215.

5. Schaafsma G. (2009), Safety of protein hydrolysates, fractions thereof and bioactive peptides in human nutrition, European Journal of Clinical Nutrition, 63, pp. 1161-1168.

6. Meghan A. (2018), Whey protein hydrolysate supplementation accelerates recovery from exercise-induced muscle damage in females, Applied Physiology, Nutrition and Metabolism, 43(4), pp. 324-330.

7. American Academy of Pediatrics. Committee on Nutrition Hypoallergenic infant formulas. (2000), Pediatrics, 106(2), pp. 346-349.

8. Koletzko S., Niggemann B., Arato A. et. al (2012), Diagnostic approach and management of cow's milk protein allergy in infants and children: ESPGHAN Gl committee practical guidelines, Journal of pediatric gastroenterology and nutrition, 55(2), pp. 221-229.

9. Tutelian V.A., Kon I.Ia. (2004), Rukovodstvo po detskomu pitaniiu, Meditsinskoe informatsionnoe agentstvo, Moskva.

10. Rigo J., Schoen S., Verghote M. et. al (2019), Partially hydrolyzed whey-based formulae with reduced protein content support adequate infant growth and are well tolerated: results of a randomized controlled trial in healthy term infants, Nutrients, 11, pp. 1654-1669.

11. Pihlanto A. (2011), Whey proteins and peptides, Nutrafoods, 10(2-3), pp. 29-42.

12. Orcajo J., Lavilla M. (2015), Cow's milk allergen $\beta$-lactoglobulin immunoreactivity affected by pulsed light treatment, Clinical and Translational Allergy, 5(3), p. 50.

13. Rangel A.H., Sales D.C., Urbano S.A. et al. (2016), Lactose intolerance and cow's milk protein allergy, Food science and Technology, 36(2), Available at: http://www.scielo.br/scielo.php?script=sci_arttext\&pid=S0101-20612016000200179.

14. Maubois J.-L., Lorient D. (2016), Dairy proteins and soy proteins in infant foods nitrogento-protein conversion factors, Dairy Science and Technology, 96(1), pp. 15-25.

15. Joyce A.M., Brodkorb A., Kelly A.L. et al. (2017), Separation of the effects of denaturation and aggregation on whey-casein protein interactions during the manufacture of a model infant formula, Dairy Science and Technology, 96, pp. 787-806. 
16. Wijayanti H.B., Bansal N., Deeth H.C. (2014), Stability of whey proteins during thermal processing: a review, Comprehensive reviews in Food Science and Food Safety, pp. 13(6), 1235-1251.

17. Dullius A., Goettert M.I. (2018), Whey protein hydrolysates as a source of bioactive peptides for functional foods - Biotechnical facilitation of industrial scale-up, Journal of Functional Foods, 42, pp. 58-74.

18. Raikos V., Dassios T. (2014), Health-promoting properties of bioactive peptides derived from milk proteins in infant food: a review, Dairy Science and Technology, 94(2), pp. 91101.

19. Sindayikengera S., Xia W. (2006), Nutritional evaluation of caseins and whey proteins and their hydrolysates from Protamex, Journal of Zhejiang University-Science B, 7(2), pp. 90 98.

20. Naik L., Mann B., Bajaj R. et al. (2013), Process optimization for the production of biofunctional whey protein hydrolysates: adopting response surface methodology, International Journal of Peptide Research and Therapeutics, 19(3), pp. 231-237.

21. Liu X., Jiang D., Peterson D.G. (2014), Identefication of bitter peptides in whey protein hydrolisate, Journal of Agricultural and Food Chemistry, 62(25), pp. 5719-5725.

22. Spellman D., O’Cuinn G., FitzGerald R.J. (2009), Bitterness in Bacillus proteins hydrolysates of whey proteins, Food Chemistry, 114(2), pp. 440-446.

23. Sujith P.A., Hymavathi T.V. (2011), Recent developments with debittering of protein hydrolysates, Asian Journal of Food and Agro-Industry, 4(06), pp. 365-381.

24. Saha B.C., Hayashi K. (2001), Debittering of protein hydrolyzates, Biotechnology Advances, 19(5), pp. 355-370.

25. Quintieri L., Monaci L., Baruzzi F., et al. (2017), Reduction of whey protein concentrate antigenicity by using a combined enzymatic digestion and ultrafiltration approach, Journal of food science and technology, 54(7), pp. 1910-1916.

26. Cho M.J., Unklesbay N., Hsieh F.H. et al. (2004), Clarke AD Hydrophobicity of bitter peptides from soy protein hydrolysates, Journal of Agricultural and Food Chemistry, 52(19), pp. 5895-5901.

27. Tchorbanov B., Marinova M., Grozeva L. (2011), Debittering of protein hydrolysates by Lactobacillus LBL-4 Aminopeptidase, Enzyme Research, 10, Available at: https://cyberleninka.org/article/n/910978/viewer.

28. FitzGerald RJ, O’Cuinn G. (2006), Enzymatic debittering of food protein hydrolysates // Biotechnology advances, 24(2), pp. 234-237.

29. Leksrisompong P., Gerard P., Lopetcharat K. et al. Bitter taste inhibiting agents for whey protein hydrolysate and whey protein hydrolysate beverages, Journal of Food Science, 77(8), pp. 282-287.

30. (2019), PeptideCutter, Available at: https://web.expasy.org/peptide_cutter/.

31. Borisova G.V., Novoselova M.V., Bondarchuk O.N., Malova Y.S (2012), Choice enzyme preparation to obtain whey hydrolyzate low allergenicity, Fundamental research, 11, pp. 1164-1167.

32. Mota M.V., Ferreira I., Olivera M. et al. (2006), Trypsin hydrolysis of whey protein concentrates: Characterization using multivariate data analysis, Food chemistry, 94(2), pp. 278-286.

33. (2017), Gilbaugh A., Kerner R.D. and John, Pediatric formula comparison guide, Available at: http://med.stanford.edu/content/dam/sm/peds/protected/core/green-teamgastro/nutrition/Stanford_Kerner_formula_guide_2017.pdf.

34. Olivera C.F., Folmer Correa A.P., Daroit D.J. et al. (2015), Soy protein hydrolysis with microbial protease to improve antioxidant and functional properties, Journal of Food Science and Technology, 52(5), pp. 2668-2678. 
35. Chi C.-H., Cho S.-J. (2015), Improvement of bioactivity of soybean meal by solid-state fermentation with Bacillus amyloliquefaciens versus Lactobacillus spp. and Saccharomyces cerevisiae, Food Science and Technology, 68, pp. 619-625.

36. Rey M.V., Ramaiya P., Nelson B.A. et al. (2004), Complete genome sequence of the industrial bacterium Bacillus licheniformis and comparison with closely related Bacillus species, Genome Biology, 5(10), Available at: https://www.ncbi.nlm.nih.gov/pmc/articles/PMC545597/.

37. Creusot N., Gruppen H. (2007), Hydrolysis of whey protein isolate with Bacillus licheniformis protease: fractionation and identification of aggregating peptides, Journal of Agricultural and Food Chemistry, 55(22), pp. 9241-9550.

38. Silvestre M., Moris H.A. (2012), Hydrolysis of whey proteins by a Bacillus licheniformis protease, Ci. Agr. Eng, Ponta Grossa, 18(2), pp. 85-94.

39. Lei F., Zhao Q., Lin L. et. al (2017), Evaluation of the hydrolysis specificity of an aminopeptidase from Bacillus licheniformis SWJS33 using synthetic peptides and soybean protein isolate, Journal of Agriculture and Food Chemistry, 65(1), pp. 167-173.

40. Jeske S., Zannini E., Cronin M.F. (2018), Impact of protease and amylase treatment on proteins and the product quality of a quinoa-based milk substitute, Food and Function, 9(6), pp. 3500-3508.

41. Mine Y., Shahidi F. (2005), Nutraceutical proteins and peptides in Health and Disease, Taylor and Francis Group, Boca Raton, Available at: https://www.ulprospector.com/en/na/Food/Detail/4497/331898/ Protamex.

42. (2019) Protamex, Available at:http://symbiotech.ru/products/proteinhydrolysis/protameks/.

43. Scopes R.K. (1985), Protein purification, Moskva.

44. Simonian M.H., Smith J.A. (2004), Spectrophotometric and colorimetric determination of protein concentration, Current Protocols in Molecular Biology, 10(10.1A).

45. Gerhardt P., Murray R. G. E., Wood W. A. et al. (1994), Methods for General and Molecular Bacteriology. American Society for Microbiology, Washington, D.C.

46. GerhardtP. (1981), Methods for General Bacteriology, American Society for Microbiology edition, Washington D.C.

47. Lazarus W. (1973), Purification of plant extracts for ion-exchange chromatography of free amino acids, Journal of Chromatography A, 87 (1), pp. 169-178.

48. NguyenP.M. (2015), Bioactive peptides from soybean hydrolysis using Protamex, Bulletin of Environment, Pharmacology and Life Sciences, 4(7), pp. 10-19.

49. Alvarado Y., Muro C., Illescas J. et al. (2019), Encapsulation of Antihypertensive Peptides from Whey Proteins and Their Releasing in Gastrointestinal Conditions, Biomolecules, 9, p. 164.

50. Mayda E. EL, Paquet D., Ramet J.P., Linden G. (1986), Proteolitic activity of a Bacillus subtilis neutral protease preparation upon caseins and whey proteins of cow's milk, Journal of Dairy Science, 69, pp. 305-310.

51. Fiocchi A., Schunemann H.J., Brozek J. (2010), World allergy organization (WAO) Diagnosis and Rationale for Action against Cow's Milk Allergy (DRACMA) Guidelines, WAO Journal, 21, pp. 57-161. 